\title{
Upgrading Conventional Activated Sludge System Using Bio-media: A Case Study of Zenin Wastewater Treatment Plant, Egypt
}

\author{
Radwa Hanafy ${ }^{1}$ Safwat M. Safwat ${ }^{2 *}$ Ehab Rozaik ${ }^{2} \quad$ Khaled Zaher $^{2}$ \\ 1.Civil Engineering Department, Institute of Aviation Engineering and Technology, Giza, Egypt \\ 2.Sanitary \& Environmental Engineering Division, Faculty of Engineering, Cairo University, Giza, Egypt
}

\begin{abstract}
This study investigated the ability to upgrade the biological treatment system in Zenin wastewater treatment plant, in Egypt. This investigation was conducted through the comparison of three different biological treatment systems: activated sludge process (AS), moving bed biofilm reactor (MBBR), and integrated fixed film activated sludge system (IFAS). Three pilot systems were established at Zenin wastewater treatment plant, to simulate AS, MBBR, and IFAS systems, to show the effect of various parameters on the removal efficiencies of biochemical oxygen demand $\left(\mathrm{BOD}_{5}\right)$, total suspended solids (TSS), and ammonium-nitrogen $\left(\mathrm{NH}_{4}-\mathrm{N}\right)$. Different values of hydraulic retention time, different amounts of returned sludge, and concentration of dissolved oxygen, were examined. The maximum removal efficiencies of $\mathrm{BOD}_{5}$, TSS, and $\mathrm{NH}_{4}-\mathrm{N}$ were $50 \%, 81.9 \%$, and $82 \%$ in activated sludge system, respectively; $80 \%, 81.8 \%$, and $99.3 \%$ in MBBR system, respectively; and $62.3 \%$, $86.2 \%$, and $76 \%$ in IFAS system, respectively.
\end{abstract}

Keywords: Attached growth; Hybrid growth; Sludge; Suspended growth; Wastewater

DOI: $10.7176 / \mathrm{CER} / 11-1-05$

\section{Introduction}

Municipal wastewater in general is comprised of water (99.9\%) together with relatively small concentrations of suspended and dissolved organic and inorganic solids (Metcalf and Eddy, 2014). The cloudiness of sewage is caused by suspended particles which in untreated sewage ranges from 100 to $350 \mathrm{mg} / \mathrm{l}$. This small percentage of organic matter is the cause of the spread of diseases and epidemics; therefore, it must be eliminated. Sewage treatment consists of three main stages: preliminary treatment, primary treatment, secondary treatment (biological treatment), and tertiary treatment. In primary treatment, the flow enters a settling tank for two to three hours to remove suspended particles, and that after the passage of wastewater through screens and grit removal chambers which represent the preliminary treatment. In these two stages, about $40 \%$ of the dissolved organic matter and $60 \%$ of the suspended solids can be eliminated. The role of biological treatment comes after that, where about $90 \%$ of the dissolved organic matter and the suspended solids can be removed (Ahmed et al., 2013; S. Safwat, 2018). This stage depends on the presence of microorganisms that consume organic matter in the presence of oxygen. In tertiary treatment, a final treatment stage is performed to further improve the effluent quality before it is discharged to the receiving environment. This can be achieved through several methods such as adsorption, electrocoagulation, etc (S. Safwat et al., 2018; Safwat and Matta, 2018; S. M. Safwat et al., 2018). There are several methods used around the world for biological treatment processes, some are based on suspended growth (e.g., the activated sludge system), and others are based on attached growth (e.g., the moving bed biofilm reactor) (Ahmed et al., 2016; Wei et al., 2016). Recently, the two methods of growth can be combined (e.g., Integrated Fixed Film Activated Sludge system (IFAS)) (Ahmed et al., 2015; Di Trapani et al., 2011; S. M. Safwat, 2018). Several parameters affect the performance of these systems (Bhatia et al., 2017; Lopez-Lopez et al., 2012; Mannina et al., 2018; Ødegaard et al., 2000; Sriwiriyarat et al., 2008).

Zenin wastewater treatment plant, located in Giza, Egypt, is constructed in 1990 (Safwat, 2012). It has three stages of treatment. The biological treatment process relies on the activated sludge system. Due to the increase in strength of influent wastewater, it is essential to upgrade the plant to improve the quality of effluent. Since no available area exists around the plant, construction of additional units will not be possible. Thus, it is feasible to upgrade the biological units without the construction of new units. This can be achieved through using bio-media.

Zenin wastewater treatment plant, which was constructed outside of urban regions, is now surrounded by residential buildings. This situation prevents the horizontal expansion of the treatment plant to meet the increase in effluent demands; and encourages the concept of compact treatment units. Since the construction of new aerobic reactors, to improve the performance of conventional activated sludge systems, is not possible, upgrading the current systems using biofilm carriers can provide a solution to this problem (S. M. Safwat, 2018). To the best of our knowledge, investigation of the ability to upgrade the biological units in Zenin wastewater treatment plant has not been reported yet. Thus, this study was conducted to investigate the performance of suspended growth systems, attached growth systems, and hybrid growth systems as biological treatment processes in Zenin wastewater treatment plant. This investigation was done through performing a comparison 
among conventional activated sludge system, moving bed biofilm reactor, and integrated fixed film activated sludge systems under the same conditions. To obtain the optimum conditions, variation in hydraulic retention time (HRT), returned sludge (RS), and concentration of dissolved oxygen (DO) were studied. Biochemical oxygen demand $\left(\mathrm{BOD}_{5}\right)$, total suspended solids (TSS), and ammonium-nitrogen $\left(\mathrm{NH}_{4}-\mathrm{N}\right)$ were measured to show the efficiency of treatment process.

\section{Materials and methods}

2.1. Characteristics of wastewater:

Primary settled wastewater from Zenin wastewater treatment plant was used to feed the biological treatment units in this study. Characteristics of the influent wastewater are shown in Table 1.

Table 1: Characteristics of influent wastewate
\begin{tabular}{|c|c|}
\hline Parameter & Value \\
\hline $\mathrm{pH}$ & 7.0 \\
\hline $\mathrm{BOD}_{5}$ & $123 \mathrm{mg} / \mathrm{l}$ \\
\hline $\mathrm{TSS}$ & $172 \mathrm{mg} / \mathrm{l}$ \\
\hline $\mathrm{NH}_{4}-\mathrm{N}$ & $26.5 \mathrm{mg} / \mathrm{l}$ \\
\hline
\end{tabular}

2.2 System setup and operating procedures:

Three pilot plants were constructed to simulate the activated sludge system (AS), the moving bed biofilm reactor (MBBR), and the integrated fixed film activated sludge system (IFAS). Each system consisted of an aeration tank as shown in Figure 1, followed by a settling tank as shown in Figure 2. The dimensions of each aeration tank were $1 * 0.5 * 0.4 \mathrm{~m}^{3}$. Polyethylene carriers (Al-Andalus Company, Egypt) were used in both MBBR and IFAS, as shown in Figure 3, with filling ratio of $60 \%$. The systems were operated using different amounts of return sludge $(\mathrm{RS}=5 \mathrm{~L}$ and $\mathrm{RS}=10 \mathrm{~L})$ in the cases of $\mathrm{AS}$ and IFAS systems. The return sludge was obtained from final settling tank located in Zenin wastewater treatment plant. Various concentrations of dissolved oxygen (3 $\mathrm{mg} / \mathrm{l}, 5.4, \mathrm{mg} / \mathrm{l}$, and $7 \mathrm{mg} / \mathrm{l}$ ) were supplied to aeration tanks in the three cases through diffused air systems. The systems were operated under three different hydraulic retention times $(2 \mathrm{~h}, 4 \mathrm{~h}$, and $6 \mathrm{~h})$. The operating temperature was $20 \pm 2{ }^{\circ} \mathrm{C}$.

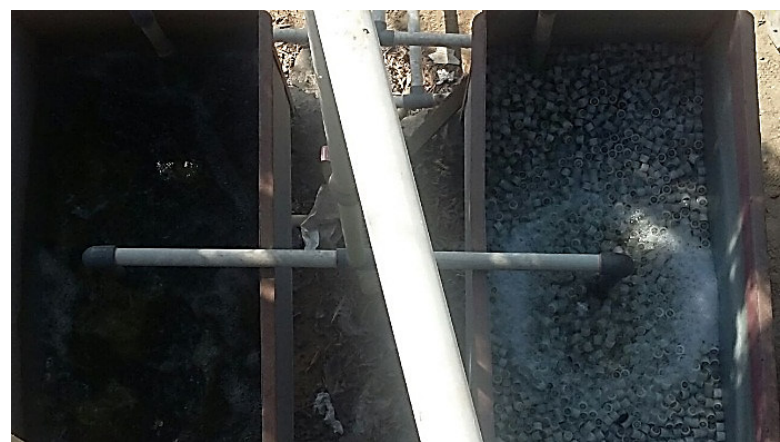

Figure 1: The aeration tank

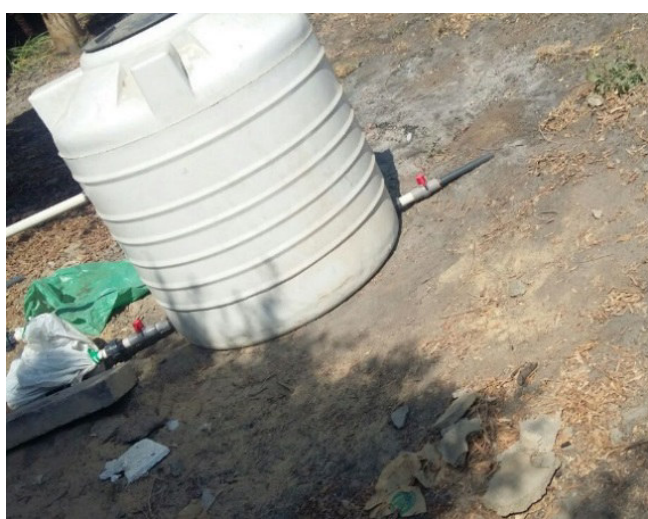

Figure 2: The settling tank 


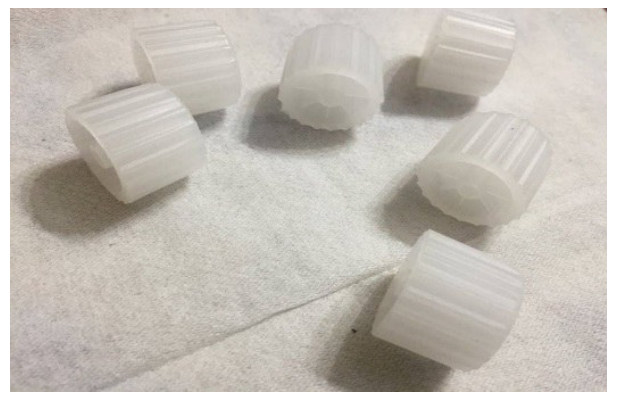

Figure 3: Polyethylene media

\subsection{Analysis:}

Samples from both influent and effluent were collected for analysis. Biochemical oxygen demand $\left(\mathrm{BOD}_{5}\right)$, total suspended solids (TSS), and ammonium-nitrogen $\left(\mathrm{NH}_{4}-\mathrm{N}\right)$ were measured for influent and effluent according to the standard methods (APHA, 2005). Aeration through bottom diffusers was used to provide oxygen at the required concentrations.

\section{Results and discussion}

3.1 Performance of three systems at DO $=3 \mathrm{mg} / \mathrm{l}$ :

3.1.1 $\mathrm{BOD}_{5}$ removal:

Figure 4 shows the $\mathrm{BOD}_{5}$ removal efficiencies for different systems during different hydraulic retention times $(2 \mathrm{~h}, 4 \mathrm{~h}$, and $6 \mathrm{~h})$ at $\mathrm{DO}=3 \mathrm{mg} / \mathrm{l}$. The maximum removal efficiency of $\mathrm{BOD}_{5}, 56 \%$, was obtained in MBBR; while the minimum removal efficiency, $32.75 \%$, was obtained in AS with RS $=10 \mathrm{~L}$. The removal efficiencies for IFAS with RS $=5 \mathrm{~L}$, AS with RS $=5 \mathrm{~L}$, and IFAS with $\mathrm{RS}=10 \mathrm{~L}$ were $48.4 \%$, $39.67 \%$, and $35 \%$, respectively. The performance of systems that contained polyethylene media were better than those without the media at the same value of the returned sludge. This may be due to the presence of media which contained additional biomass on its surface. Also, these carriers were able to move all around the tank during the operation, and led to better contact with the substrate, which in turn resulted in better biodegradation of the organic matter. In IFAS system, the removal of $\mathrm{BOD}_{5}$ decreased with increasing the value of the returned sludge. This may be due to the increase of the sludge age (SRT) in the reactor beyond the optimum levels, which resulted in decreasing the efficiency of the treatment process. In AS system, the removal of $\mathrm{BOD}_{5}$ decreased with increasing the value of the returned sludge. This may be due to the increase of the SRT in the reactor beyond the optimum levels, which resulted in decreasing the efficiency of the treatment process.

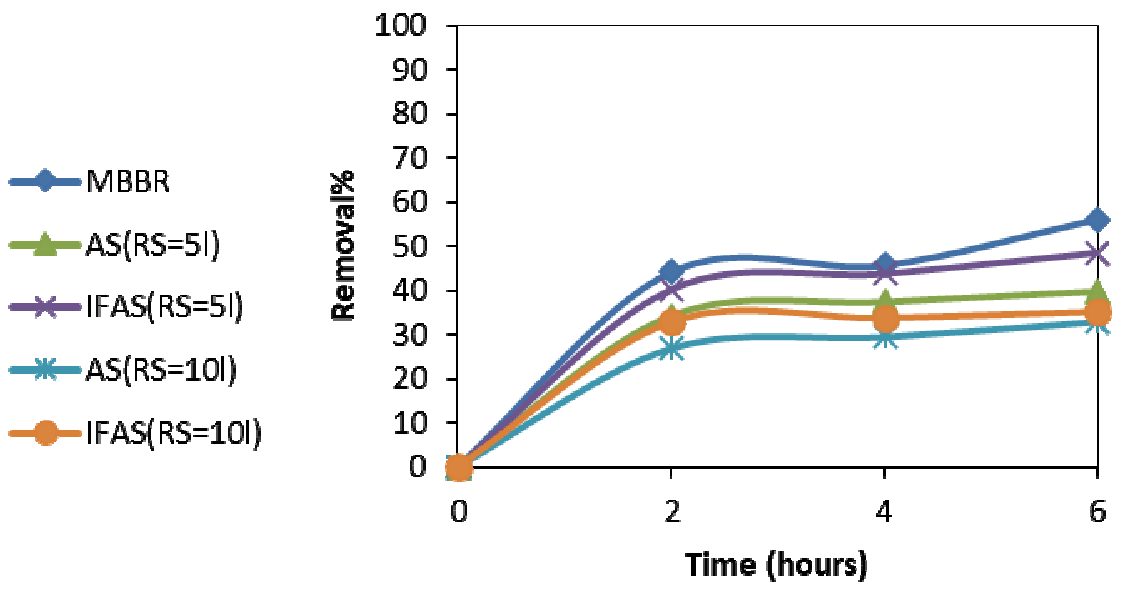

Figure 4: $\mathrm{BOD}_{5}$ removal efficiency for different systems at $\mathrm{DO}=3 \mathrm{mg} / \mathrm{l}$

3.1.2 TSS Removal:

Figure 5 shows the TSS removal efficiency for different systems during different hydraulic retention times $(2 \mathrm{~h}, 4 \mathrm{~h}$, and $6 \mathrm{~h})$ at DO $=3 \mathrm{mg} / \mathrm{l}$. The maximum removal efficiency of TSS, $78.3 \%$, was obtained in MBBR; while the minimum removal efficiency, $13.66 \%$, was obtained in AS with RS $=10 \mathrm{~L}$. The removal efficiencies for IFAS with $\mathrm{RS}=5 \mathrm{~L}$, AS with $\mathrm{RS}=5 \mathrm{~L}$, and IFAS with $\mathrm{RS}=10 \mathrm{~L}$ were $37.68 \%, 27.8 \%$, and $24.3 \%$, respectively. The performance of the systems that contained polyethylene media were better than those without the media at the same value of the returned sludge. This may be due to the presence of media which contained additional biomass on its surface. Also, these carriers were able to move all around the tank during the operation resulting in better contact with the substrate, which in turn resulted in better biodegradation of organic matter. In 
IFAS system, the removal of TSS decreased with increasing the value of returned sludge. This may be due to the increasing of the SRT in the reactor beyond the optimum levels, resulting in decreasing the efficiency of the treatment process. In AS system, the removal of TSS decreased with increasing the value of returned sludge. This may be due to the increasing of the SRT in the reactor beyond the optimum levels, resulting in decreasing the efficiency of the treatment process.
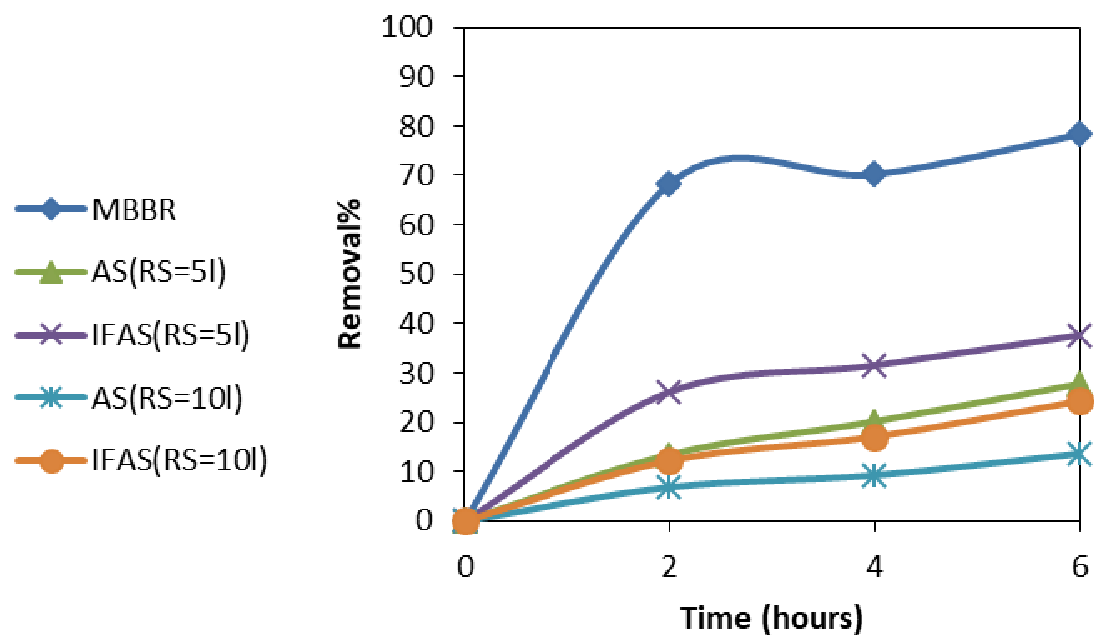

Figure 5: TSS removal efficiency for different systems at DO $=3 \mathrm{mg} / \mathrm{l}$

3.1.3 $\mathrm{NH}_{4}$ Removal:

Figure 6 shows the $\mathrm{NH}_{4}$ removal efficiency for different systems during different hydraulic retention times $(2 \mathrm{~h}, 4 \mathrm{~h}$, and $6 \mathrm{~h})$ at $\mathrm{DO}=3 \mathrm{mg} / \mathrm{l}$. The maximum removal efficiency of $\mathrm{NH}_{4}, 47.12 \%$, was obtained in IFAS with $\mathrm{RS}=5 \mathrm{~L}$; while the minimum removal efficiency, $21.7 \%$, was obtained in AS with RS=10 L. The removal efficiencies for MBBR, IFAS with RS= $10 \mathrm{~L}$, and AS with $\mathrm{RS}=5 \mathrm{~L}$ were $43.3 \%, 32.7 \%$, and $28 \%$, respectively. The performance of systems that contained polyethylene media were better than those without the media at the same value of the returned sludge. This may be due to the presence of media which contained additional biomass on its surface. Also, these carriers were able to move all around the tank during the operation resulting in better contact with the substrate, which in turn resulted in better biodegradation of organic matter. In addition, carriers supported the growth of nitrifying bacteria, thus allowing better nitrification performance. The IFAS at RS $=5 \mathrm{~L}$ system was more efficient than the MBBR system in $\mathrm{NH}_{4}$ removal. This may be due to the increasing in the SRT in the IFAS system when compared to the MBBR system, which improved the nitrification process. In IFAS system, the removal of $\mathrm{NH}_{4}$ decreased with increasing the value of the returned sludge. This may be due to the increasing in the biomass which consumed the dissolved oxygen. As a result, the dissolved oxygen decreased, which in turn affected the growth rate of the nitrifying bacteria. In AS system, the removal of $\mathrm{NH}_{4} \mathrm{decreased}$ with increasing the value of the returned sludge. This may be due to the increasing in the biomass which consumed the dissolved oxygen. As a result, the dissolved oxygen decreased, which in turn affected the growth rate of the nitrifying bacteria. 

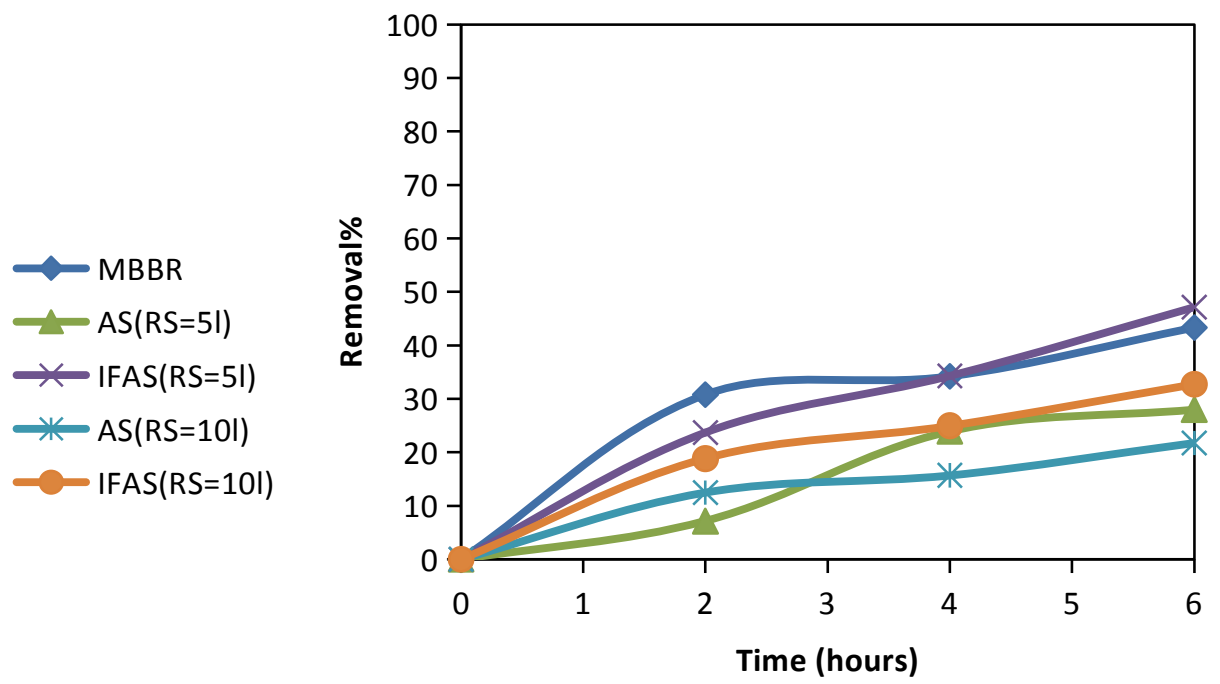

Figure 6: $\mathrm{NH}_{4}$ removal efficiency for different systems at DO $=3 \mathrm{mg} / \mathrm{l}$

\subsection{Performance of three systems at DO $=5.4 \mathrm{mg} / \mathrm{l}$}

\subsection{1 $\mathrm{BOD}_{5}$ Removal:}

Figure 7 shows the $\mathrm{BOD}_{5}$ removal efficiency for different systems during different hydraulic retention times $(2 \mathrm{~h}, 4 \mathrm{~h}$, and $6 \mathrm{~h})$ at $\mathrm{DO}=5.4 \mathrm{mg} / \mathrm{l}$. The maximum removal efficiency of $\mathrm{BOD}_{5}, 80 \%$, was obtained in MBBR; while the minimum removal efficiency, $41.14 \%$, was obtained in AS with RS $=10 \mathrm{~L}$. The removal efficiencies for IFAS with $\mathrm{RS}=5 \mathrm{~L}$, AS with $\mathrm{RS}=5 \mathrm{~L}$, and IFAS with $\mathrm{RS}=10 \mathrm{~L}$ were $55.56 \%, 50 \%$, and $47.78 \%$, respectively. The performance of systems that contained polyethylene media were better than those without the media at the same value of the returned sludge. This may be due to the presence of media which contained additional biomass on its surface. Also, these carriers were able to move all around the tank during the operation, resulting in better contact with the substrate, which in turn resulted in better biodegradation of the organic matter. In IFAS system, the removal of $\mathrm{BOD}_{5}$ decreased with increasing the value of the returned sludge. This may be due to the increasing of the SRT in the reactor beyond the optimum levels, resulting in decreasing the efficiency of the treatment process. In AS system, the removal of $\mathrm{BOD}_{5}$ decreased with increasing the value of the returned sludge. This may be due to the increasing of the SRT in the reactor beyond the optimum levels, resulting in decreasing the efficiency of the treatment process.

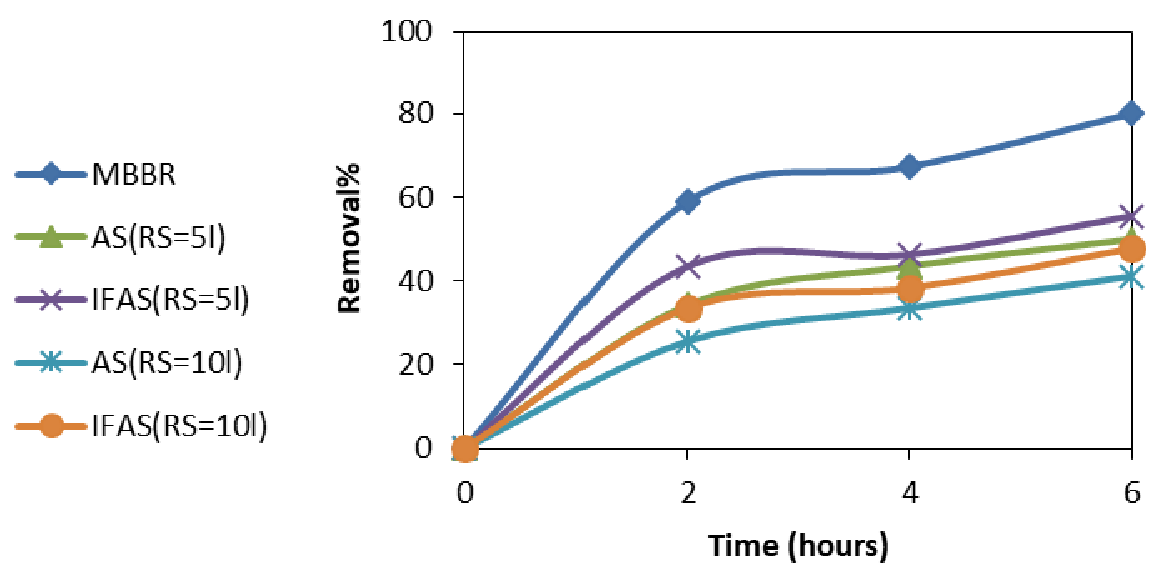

Figure 7: $\mathrm{BOD}_{5}$ removal efficiency for different systems at $\mathrm{DO}=5.4 \mathrm{mg} / \mathrm{l}$

3.2.2 TSS Removal:

Figure 8 shows the TSS removal efficiency for different systems during different hydraulic retention times $(2 \mathrm{~h}, 4 \mathrm{~h}$, and $6 \mathrm{~h})$ at DO $=5.4 \mathrm{mg} / \mathrm{l}$. The maximum removal efficiency of TSS, $86.17 \%$, was obtained in IFAS with $\mathrm{RS}=10 \mathrm{~L}$; while the minimum removal efficiency, $66.28 \%$, was obtained in AS with $\mathrm{RS}=5 \mathrm{~L}$. The removal efficiencies for $\mathrm{AS}$ with $\mathrm{RS}=10 \mathrm{~L}, \mathrm{MBBR}$, and IFAS with $\mathrm{RS}=5 \mathrm{~L}$ were $81.91 \%, 81.82 \%$, and $73.26 \%$, respectively. The performance of systems that contained polyethylene media were better than those without the media at the same value of return sludge. This may be due to the presence of media which contained 
additional biomass on its surface. Also, these carriers were able to move all around the tank during the operation resulting in better contact with the substrate, which in turn resulted in better biodegradation of the organic matter. In all IFAS and AS systems, when the value of the returned sludge increased, the efficiency of the treatment process increased. This may be due to the increasing of the SRT in the reactor.
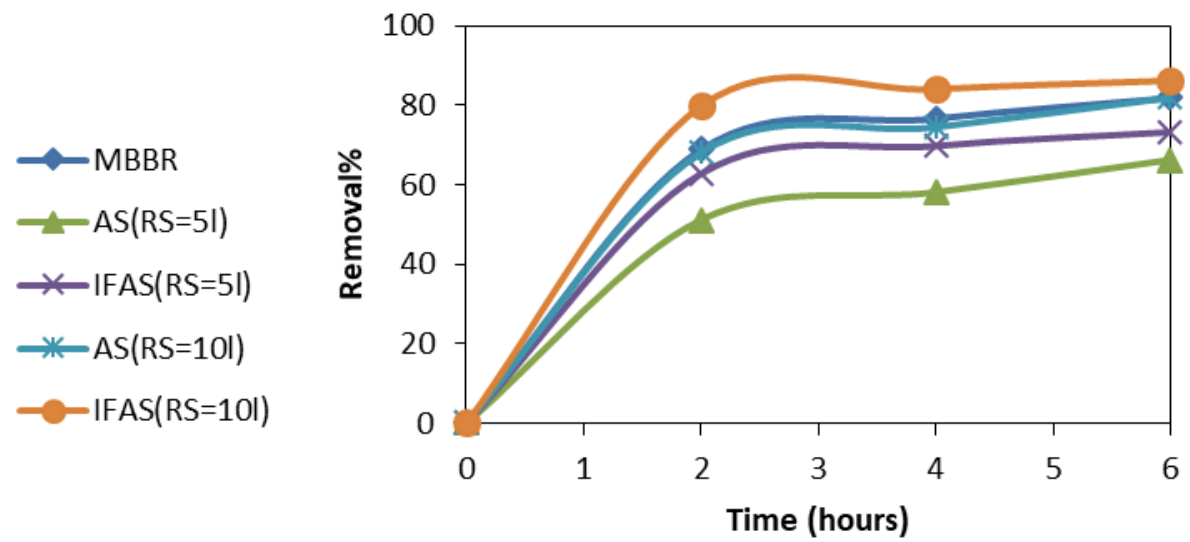

3.2.3 $\mathrm{NH}_{4}$ Removal:

Figure 8: TSS removal efficiency for different systems at DO $=5.4 \mathrm{mg} / \mathrm{l}$

Figure 9 shows the $\mathrm{NH}_{4}$ removal efficiency for different systems during different hydraulic retention times $(2 \mathrm{~h}, 4 \mathrm{~h}$, and $6 \mathrm{~h})$ at $\mathrm{DO}=5.4 \mathrm{mg} / \mathrm{l}$. The maximum removal efficiency of $\mathrm{NH}_{4}, 99.35 \%$, was obtained in MBBR; while the minimum removal efficiency, $53.3 \%$, was obtained in AS with RS=5 L. The removal efficiencies for IFAS with $\mathrm{RS}=10 \mathrm{~L}$, IFAS with $\mathrm{RS}=5 \mathrm{~L}$, and AS with $\mathrm{RS}=10 \mathrm{~L}$ were $76 \%, 68.6 \%$, and $56.8 \%$, respectively. The performance of systems that contained polyethylene media were better than those without the media at the same value of the returned sludge. This may be due to the presence of media which contained additional biomass on its surface. Also, these carriers were able to move all around the tank during the operation resulting in better contact with the substrate, which in turn resulted in better biodegradation of the organic matter. In addition, carriers supported the growth of the nitrifying bacteria, thus allowing better nitrification performance. In all IFAS and AS systems, when the value of returned sludge increased, the efficiency of the treatment process increased. In this case, the amount of oxygen is sufficient for the growth of the nitrifying bacteria; as a result, the efficiency of $\mathrm{NH}_{4}$ removal increased with increasing the returned sludge due to the increase in the amount of the heterotrophic bacteria, which caused a rapid consumption of the carbonaceous organic matter at the beginning of treatment process. After that, the nitrifying bacteria were able to consume ammonia.
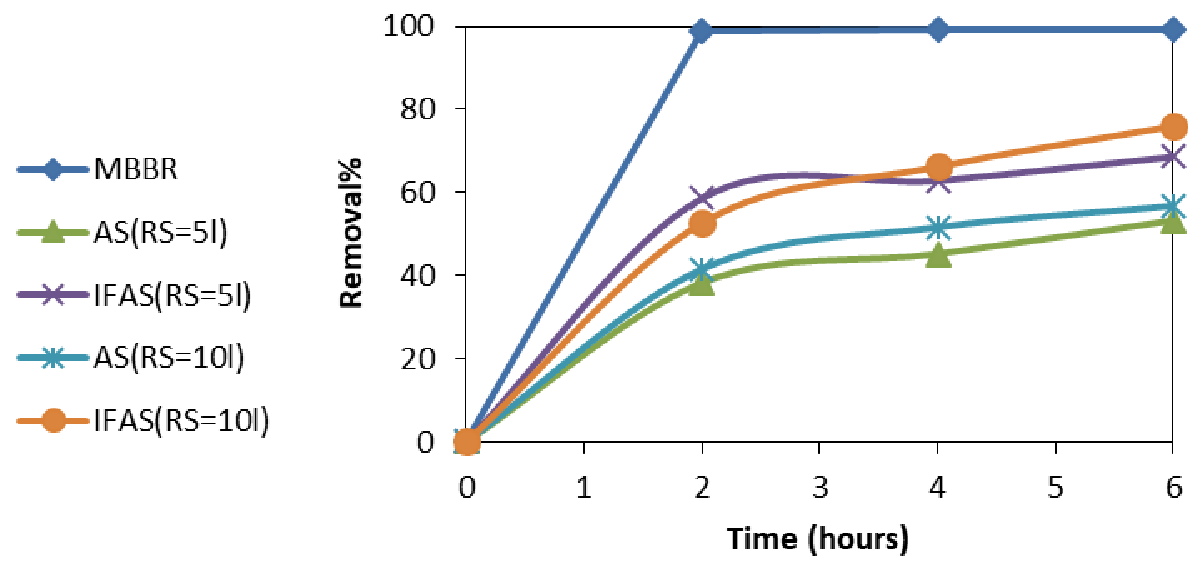

Figure 9: $\mathrm{NH}_{4}$ removal efficiency for different systems at $\mathrm{DO}=5.4 \mathrm{mg} / \mathrm{l}$

\subsection{Performance of three systems at $D O=7 \mathrm{mg} / \mathrm{l}$ :}

3.3.1 $\mathrm{BOD}_{5}$ Removal:

Figure 10 shows the $\mathrm{BOD}_{5}$ removal efficiency for different systems during different hydraulic retention times $(2 \mathrm{~h}, 4 \mathrm{~h}$, and $6 \mathrm{~h})$ at $\mathrm{DO}=7 \mathrm{mg} / \mathrm{l}$. The maximum removal efficiency of $\mathrm{BOD}_{5}, 75.78 \%$, was obtained in MBBR; while the minimum removal efficiency, $42.52 \%$, was obtained in AS with RS $=10 \mathrm{~L}$. The removal efficiencies for IFAS with $\mathrm{RS}=5 \mathrm{~L}$, IFAS with $\mathrm{RS}=10 \mathrm{~L}$, and AS with $\mathrm{RS}=5 \mathrm{~L}$ were $62.3 \%$, $59.56 \%$, and $49 \%$, respectively. The performance of systems that contained polyethylene media were better than those without the 
media at the same value of the returned sludge. This may be due to the presence of media which contained additional biomass on its surface. Also, these carriers were able to move all around the tank during the operation, resulting in better contact with the substrate, which in turn resulted in better biodegradation of the organic matter. In IFAS system, the removal of $\mathrm{BOD}_{5}$ decreased with increasing the value of the returned sludge. This may be due to the increasing of the SRT in the reactor beyond the optimum levels, resulting in decreasing the efficiency of the treatment process. In AS system, the removal of $\mathrm{BOD}_{5}$ decreased with increasing the value of the returned sludge. This may be due to the increasing of the SRT in the reactor beyond the optimum levels, resulting in decreasing the efficiency of the treatment process.
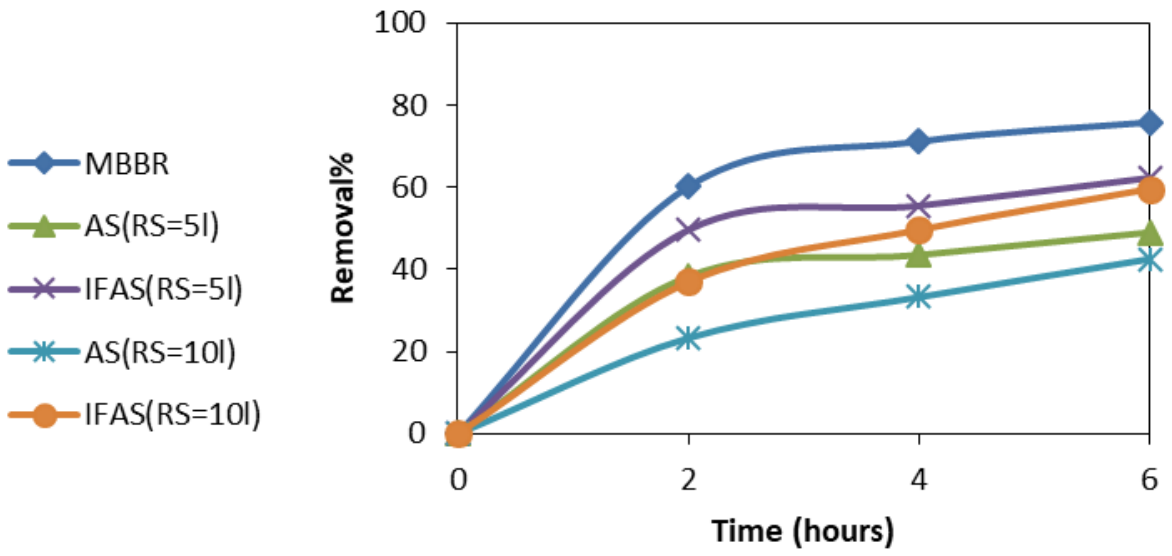

Figure 10: $\mathrm{BOD}_{5}$ removal efficiency for different systems at $\mathrm{DO}=7 \mathrm{mg} / \mathrm{l}$

\subsubsection{TSS Removal:}

Figure 11 shows the TSS removal efficiency for different systems during different hydraulic retention times $(2 \mathrm{~h}, 4 \mathrm{~h}$, and $6 \mathrm{~h})$ at DO $=7 \mathrm{mg} / \mathrm{l}$. The maximum removal efficiency of TSS, $82.6 \%$, was obtained in IFAS with $\mathrm{RS}=5 \mathrm{~L}$; while the minimum removal efficiency, $42.5 \%$, was obtained in AS with RS=10 L. The removal efficiencies for MBBR, AS with $\mathrm{RS}=5 \mathrm{~L}$, and IFAS with $\mathrm{RS}=10 \mathrm{~L}$ were $78.95 \%, 74.12 \%$, and $59.6 \%$, respectively. The performance of systems that contained polyethylene media were better than those without the media at the same value of the returned sludge. This may be due to the presence of media which contained additional biomass on its surface. Also, these carriers were able to move all around the tank during the operation, resulting in better contact with the substrate, which in turn resulted in better biodegradation of the organic matter. In IFAS system, the removal of TSS decreased with increasing the value of the returned sludge. This may be due to the increasing of the SRT in the reactor beyond the optimum levels, resulting in decreasing the efficiency of the treatment process. In AS system, the removal of TSS decreased with increasing the value of the returned sludge. This may be due to the increasing of the SRT in the reactor beyond the optimum levels, resulting in decreasing the efficiency of the treatment process.

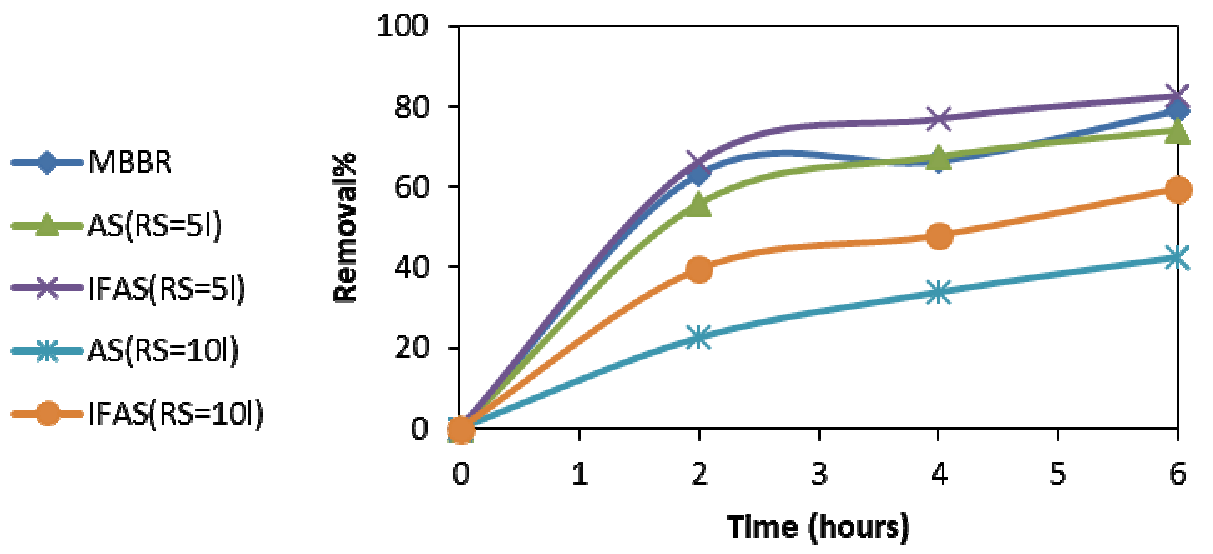

Figure 11: TSS removal efficiency for different systems at DO $=7 \mathrm{mg} / \mathrm{l}$

3.3.3 $\mathrm{NH}_{4}$ Removal:

Figure 12 shows the $\mathrm{NH}_{4}$ removal efficiency for different systems during different hydraulic retention times $(2 \mathrm{~h}, 4 \mathrm{~h}$, and $6 \mathrm{~h})$ at $\mathrm{DO}=7 \mathrm{mg} / \mathrm{l}$. The maximum removal efficiency of $\mathrm{NH}_{4}, 82.1 \%$, was obtained in $\mathrm{AS}$ with $\mathrm{RS}=$ $10 \mathrm{~L}$; while the minimum removal efficiency, $36.17 \%$, was obtained in $\mathrm{AS}$ with $\mathrm{RS}=5 \mathrm{~L}$. The removal efficiencies for IFAS with RS= 5 L, MBBR, and IFAS with RS= 10 were $57.4 \%, 52.17 \%$, and $45.8 \%$, 
respectively. The performance of AS system was better than systems that contain polyethylene media at the same amount of the returned sludge. This is may be due to the increase in the dissolved oxygen concentration to some extent, which affected the nitrification process. Excess dissolved oxygen might lead to excess growth of the heterotrophic bacteria on the surface of the carriers. In AS system, when the value of the returned sludge increased, the efficiency of the treatment process increased. In this case, the amount of oxygen is sufficient for the growth of the nitrifying bacteria, as a result the efficiency of $\mathrm{NH}_{4}$ removal increased with increasing the returned sludge due to the increase in the amount of the heterotrophic bacteria which caused a rapid consumption of the carbonaceous organic matter at the beginning of treatment process. After that, nitrifying bacteria were able to consume ammonia. In IFAS system, the removal of $\mathrm{NH}_{4}$ decreased with increasing the amount of the returned sludge. This may be due to the increasing in the biomass which consumed the dissolved oxygen. As a result, the dissolved oxygen decreased, which in turn affected the growth rate of the nitrifying bacteria.

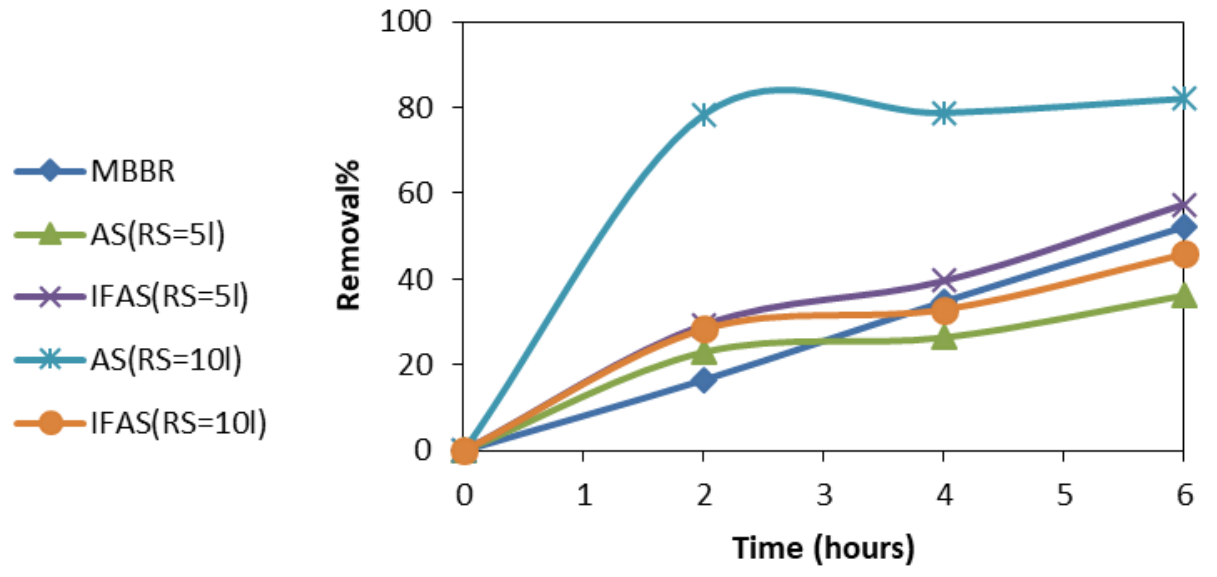

Figure 12: $\mathrm{NH}_{4}$ removal efficiency for different systems at $\mathrm{DO}=7 \mathrm{mg} / \mathrm{l}$

\subsection{Performance of three systems based on the amount of the dissolved oxygen}

3.4.1 $\mathrm{BOD}_{5}$ Removal:

In MBBR system, the optimum removal efficiency of $\mathrm{BOD}_{5}$ was obtained at $\mathrm{DO}=5.4 \mathrm{mg} / \mathrm{l}$, and this is because the percentage of the media used in the system was $60 \%$ of the total volume of reactor, and this percentage is less than the recommended value in the literature (up to 70\%) (Metcalf and Eddy, 2014). The performance of MBBR system was not good at DO $=7 \mathrm{mg} / \mathrm{l}$, this is due to the increase in the mixing process, which led to a high collision between carriers, and in turn the slough off of the biofilm from the surface of the media. In IFAS systems, the optimum removal efficiency of $\mathrm{BOD}_{5}$ was obtained at $\mathrm{DO}=7 \mathrm{mg} / \mathrm{l}$ and this amount of oxygen is suitable for the growth and reproduction of the biofilm on the carriers. Generally, in AS system, the range of the dissolved oxygen, which gives better removal efficiency for $\mathrm{BOD}_{5}$, was about 4-6 mg/l, except for the AS system at RS $=10 \mathrm{~L}$. This may be due to the increasing in the organic content which needed more amount of dissolved oxygen for the oxidation process.

3.4.2 TSS Removal:

In MBBR system, the optimum removal efficiency of TSS was obtained at DO $=5.4 \mathrm{mg} / \mathrm{l}$, and this is because the percentage of the media, which was used in the system, was $60 \%$ of the total volume of reactor, and this percentage is less than the recommended value in the literature (up to 70\%). The performance of MBBR system was not good at DO $=7 \mathrm{mg} / \mathrm{l}$, this is due to the increase in the mixing process, which led to a high collision between carriers, and in turn the slough off of the biofilm from the surface of media. In IFAS system at RS $=10$ $\mathrm{L}$, the optimum removal efficiency of TSS was at DO $=5.4 \mathrm{mg} / \mathrm{l}$, and the performance of system was not good at $\mathrm{DO}=7 \mathrm{mg} / \mathrm{l}$, this is due to the increase in the mixing process, which led to a high collision between carriers, and in turn the slough off of the biofilm from the surface of the media. In AS system, at $\mathrm{RS}=5 \mathrm{~L}$, the optimum removal efficiency of TSS was achieved at $\mathrm{DO}=7 \mathrm{mg} / \mathrm{l}$, while in AS system, at RS $=10 \mathrm{~L}$, the optimum removal efficiency of TSS was achieved at DO $=5.4 \mathrm{mg} / \mathrm{l}$, and the performance of system was not good at DO $=7 \mathrm{mg} / \mathrm{l}$. The increase in DO led to the occurrence of sludge bulking, which made the sludge to be slimy and of jellylike consistency. This caused a problem in the settling of the solids, which affected the removal efficiency of TSS.

3.4.3 $\mathrm{NH}_{4}$ Removal:

In the MBBR system, it was found that the optimum removal efficiency of $\mathrm{NH}_{4}$ was $99.35 \%$, and obtained at $\mathrm{DO}=5.4 \mathrm{mg} / \mathrm{l}$. In the IFAS system with $(\mathrm{RS}=5 \mathrm{~L})$, it was found that the optimum removal efficiency of $\mathrm{NH}_{4}$ was $68.6 \%$, and obtained at DO $=5.4 \mathrm{mg} / \mathrm{l}$. In the IFAS system with $\left(\mathrm{Q}_{\mathrm{s}}=10 \mathrm{~L}\right)$, the optimum removal efficiency of $\mathrm{NH}_{4}$ was $76 \%$, and obtained at $\mathrm{DO}=5.4 \mathrm{mg} / \mathrm{l}$. In the AS system with $\left(\mathrm{Q}_{\mathrm{s}}=5 \mathrm{~L}\right)$, the optimum removal 
efficiency of $\mathrm{NH}_{4}$ was $53.3 \%$, and obtained at $\mathrm{DO}=5.4 \mathrm{mg} / \mathrm{l}$. In the AS system with $\left(\mathrm{Q}_{\mathrm{s}}=10 \mathrm{~L}\right)$, the optimum removal efficiency of $\mathrm{NH}_{4}$ was $82.1 \%$, and obtained at $\mathrm{DO}=7 \mathrm{mg} / \mathrm{l}$. Generally, in aeration systems, the best rates of the nitrification process are at dissolved oxygen up to $2 \mathrm{mg} / \mathrm{l}$ and in the range of 3.5-5.5 mg/l. This has been achieved for all values of RS except for AS system at RS $=10 \mathrm{~L}$. This may be due to the increase in the organic content which needed more amount of the dissolved oxygen for the oxidation process.

\section{Conclusions}

The ability to upgrade aeration tanks through bio-media were investigated. Based on the obtained results, one can conclude the following:

1. The performance of systems that contained polyethylene media were better than those without the media at the same value of the returned sludge.

2. The MBBR was able to achieve the maximum removal of $\mathrm{BOD}_{5}$ at $\mathrm{DO}=5.4 \mathrm{mg} / \mathrm{l}$.

3. The IFAS system at $\mathrm{RS}=5 \mathrm{~L}$ was able to achieve the maximum removal of $\mathrm{BOD}_{5}$ at $\mathrm{DO}=7 \mathrm{mg} / \mathrm{l}$.

4. In IFAS system, the increase of the values of the returned sludge and the DO resulted in decreasing in the TSS removal efficiency.

5. In AS system, the increase of the values of the returned sludge and the DO resulted in decreasing the TSS removal efficiency.

6. The removal efficiency of $\mathrm{NH}_{4}-\mathrm{N}$ was higher in the IFAS system at $\mathrm{RS}=5 \mathrm{~L}$, than that in MBBR system at $\mathrm{DO}=7 \mathrm{mg} / \mathrm{l}$. On the other hand, when the value of the DO decreased to $5.4 \mathrm{mg} / \mathrm{l}$, the removal efficiency was improved in MBBR.

7. The optimum removal efficiencies of $\mathrm{MBBR}$ for $\mathrm{BOD}_{5}, \mathrm{TSS}$, and $\mathrm{NH}_{4}-\mathrm{N}$ were obtained at $\mathrm{DO}=5.4$ $\mathrm{mg} / \mathrm{l}$.

8. The optimum removal efficiencies of IFAS for $\mathrm{BOD}_{5}, \mathrm{TSS}$, and $\mathrm{NH}_{4}-\mathrm{N}$ were obtained at DO $=7 \mathrm{mg} / \mathrm{l}$.

9. It is feasible to upgrade biological units in Zenin wastewater treatment plant using bio-media.

\section{References}

Ahmed, S., Abdelhalim, H., Rozaik, E., 2013. Treatment of Primary Settled Wastewater Using Anaerobic Sequencing Batch Reactor Seeded with Activated EM. Civ. Environ. Res.

Ahmed, S., Rozaik, E., Abdelhalim, H., 2016. Performance of Single-Chamber Microbial Fuel Cells Using Different Carbohydrate-Rich Wastewaters and Different Inocula. Polish J. Environ. Stud. 25, 503-510. https://doi.org/10.15244/pjoes/61115

Ahmed, S., Rozaik, E., Abdelhalim, H., 2015. Effect of Configurations, Bacterial Adhesion, and Anode Surface Area on Performance of Microbial Fuel Cells Used for Treatment of Synthetic Wastewater. Water, Air, Soil Pollut. 226, 300. https://doi.org/10.1007/s11270-015-2567-3

APHA, 2005. No Title. American Public Health Association/American Water Works Association/Water Environment Federation, Washington DC.

Bhatia, A., Singh, N.K., Bhando, T., Pathania, R., Kazmi, A.A., 2017. Effect of intermittent aeration on microbial diversity in an intermittently aerated IFAS reactor treating municipal wastewater: A field study. J. Environ. Sci. Heal. - Part A Toxic/Hazardous Subst. Environ. Eng. 52, 440-448. https://doi.org/10.1080/10934529.2016.1271665

Di Trapani, D., Christensso, M., Ødegaard, H., 2011. Hybrid activated sludge/biofilm process for the treatment of municipal wastewater in a cold climate region: A case study. Water Sci. Technol. 63, 1121-1129. https://doi.org/10.2166/wst.2011.350

Lopez-Lopez, C., Martín-Pascual, J., González-Martínez, A., Calderón, K., González-López, J., Hontoria, E., Poyatos, J.M., 2012. Influence of filling ratio and carrier type on organic matter removal in a moving bed biofilm reactor with pretreatment of electrocoagulation in wastewater treatment. J. Environ. Sci. Heal. - Part A Toxic/Hazardous Subst. Environ. Eng. 47, 1759-1767. https://doi.org/10.1080/10934529.2012.689223

Mannina, G., Capodici, M., Cosenza, A., Di Trapani, D., Ekama, G.A., 2018. The effect of the solids and hydraulic retention time on moving bed membrane bioreactor performance. J. Clean. Prod. 170, 1305-1315. https://doi.org/10.1016/j.jclepro.2017.09.200

Metcalf, Eddy, 2014. Wastewater Engineering: Treatment and Resource Recovery. McGraw-Hill.

Ødegaard, H., Gisvold, B., Strickland, J., 2000. The influence of carrier size and shape in the moving bed biofilm process. Water Sci. Technol. 41, 383-391. https://doi.org/10.1016/j.bej.2017.05.005

Safwat, S., 2018. Coupling Microbial Fuel Cells with Electrocoagulation Cells to form an Integrated System for Wastewater Treatment. Polish J. Environ. Stud. 28, 1-7. https://doi.org/10.15244/pjoes/89543

Safwat, S., Hamed, A., Rozaik, E., 2018. Electrocoagulation/Electroflotation of Real Printing Wastewater Using Copper Electrodes: A Comparative Study with Aluminum Electrodes. Sep. Sci. Technol. https://doi.org/10.1080/01496395.2018.1494744

Safwat, S., Matta, M., 2018. Adsorption of Urea onto Granular Activated Alumina: A Comparative Study with 
Granular Activated Carbon. J. Dispers. Sci. Technol. 39, 1699-1709. https://doi.org/10.1080/01932691.2018.1461644

Safwat, S.M., 2018. Performance of Moving Bed Biofilm Reactor Using Effective Microorganisms. J. Clean. Prod. 185, 723-731.

Safwat, S.M., 2012. Effect of using effective microorganisms in anaerobic sequencing batch reactor for municipal wastewater treatment. CU Theses.

Safwat, S.M., Medhat, M., Abdel-Halim, H., 2018. Adsorption of phenol onto aluminium oxide and zinc oxide: A comparative study with titanium dioxide. Sep. Sci. Technol. 0, 1-13. https://doi.org/10.1080/01496395.2018.1549572

Sriwiriyarat, T., Pittayakool, K., Fongsatitkul, P., Chinwetkitvanich, S., 2008. Stability and capacity enhancements of activated sludge process by IFAS technology. J. Environ. Sci. Heal. - Part A Toxic/Hazardous Subst. Environ. Eng. 43, 1318-1324. https://doi.org/10.1080/10934520802177961

Wei, Y., Yin, X., Qi, L., Wang, H., Gong, Y., Luo, Y., 2016. Effects of carrier-attached biofilm on oxygen transfer efficiency in a moving bed biofilm reactor. Front. Environ. Sci. Eng. 10, 569-577. https://doi.org/10.1007/s11783-015-0822-x 